14 Rosati C, Hannaert P, Dausse JP, Braquet P, Garay R. Stimulation of beta-adrenoceptors inhibits calcium-dependent potassium channels in mouse macrophages. J Cell Physiol 1986; 129:310-4.

15 Canessa ML, Morgan K, Semplicini A. Genetic differences in lithium-sodium exchange and regulation of the sodiumhydrogen exchanger in essential hypertension. $J$ Cardiovasc Pharmacol 1988;12:S92-8.

16 Canessa M, Adragna N, Solomon HS, Connolly TM, Tosteson DC. Increased sodium-lithium countertransport in red cells of patients with essential hypertension. New Engl J Med 1980; 302:772-6.

17 Swarts HGP, Bonting SL, De Pont JJ HHM, SchuurmansStekhoven FMAH, Thien TA, Van 't Laar A. Cation fluxes and $\mathrm{Na}^{+}, \mathrm{K}^{+}$-activated ATPase activity in erythrocytes of patients with essential hypertension. Hypertension 1981; 3:641-9.

18 Woodman DD. Detection of blood in faeces. Clin Chim Acta 1970;29:249-52.

19 Nechay BR, Saunders JP. Inhibition of renal adenosine triphosphatase by cadmium. J Pharmacol Exp Ther 1977;200:623-9.

20 King RG, Sharp JA, Boura ALA. The effects of $\mathrm{Al}^{3+}, \mathrm{Cd}^{2+}$ and $\mathrm{Mn}^{2+}$ on human erythrocyte choline transport. Biochem Pharmacol 1983;23:3611-7.

21 Rifkin $\mathrm{JR}$. In vitro inhibition of $\mathrm{Na}^{+}, \mathrm{K}^{+}$and $\mathrm{Mg}^{2+}-\mathrm{ATPases}$ by mono-, di- and trivalent cations. Proc Soc Exp Biol Med 1965;120:802-4.

22 Bader $\mathrm{H}$, Wilkes AB, Jean DH. The effect of hydroxylamine mercaptans, divalent metals and chelators on $\mathrm{Na}^{+}, \mathrm{K}^{+}-$ ATPase. Biochim Biophys Acta 1970;198:583-93.

\section{Lead to unusual places}

I suppose one could write a book about unusual occurrences of lead poisoning, and they keep cropping up from time to time. Every few months there is a report of someone being poisoned from contaminated home made wine or other foodstuffs and recently I remember reading about a family in the United States who had got lead poisoning after their father had enthusiastically rubbed down all the paint in their old house with dry sandpaper. This case first came to light when their vet diagnosed lead poisoning in their dog; the human doctors hadn't considered it when dealing with the other members of the household. Those who know something about the history of lead poisoning are rarely surprised by these revelations but I have come across one lead hazard of which I was not previously aware.

My first indication of it came when I was talking to a young man who was working in a joinery firm in the east end of London. His job was to feed wood through the circular saw and he came to see me because he had cut a thumb off and there was a question of the allocation of blame and settlement of damages. I asked him about his work and whether anyone else had suffered any injuries. It was all right, he said, but you had to watch out for bits flying off the saw.

"Why?"

"Because of the bullets."
23 Hexum TD. Studies on the reaction catalyzed by transport $(\mathrm{Na}$, K) adenosine triphosphatase. Effects of divalent metals. Biochem Pharmacol 1974;23:3441-7.

24 Jacobson KB, Turner JE. The interaction of cadmium and certain other metal ions with protein and nucleic acids. Toxicology 1980;16:1-37.

26 Skou JC. Study on the $\mathrm{Na}^{+}+\mathrm{K}^{+}$activated ATP hydrolysing enzyme system. The role of $\mathrm{SH}$ groups. Biochem Biophys Res Commun 1963;10:79-84.

26 Glynn IM. Transport adenosine triphosphatase in electric organ. The relation between ion transport and oxidative phosphorylation. J Physiol (Lond) 1963;169:452-65.

27 Elinder GG. Normal values for cadmium in human tissues, blood and urine in different countries. In: Friberg L, Elinder CG, Kjellström T, Nordberg GF, eds. Cadmium and health: $a$ toxicological and epidemiological appraisal. Boca Raton, Florida: 1985:82-98.

28 Plishker GA. Effects of cadmium and zinc on calcium uptake in human red blood cells. Am J Physiol 1984;247:C143-9.

29 Kunimoto $\mathbf{M}$, Miura T, Kubota $\mathbf{K}$. An apparent acceleration of age-related changes of rat blood cells by cadmium. Toxicol Appl Pharmacol 1985;77:451-7.

30 Kunimoto $M$, Miyasaka $\mathrm{K}$, Miura $\mathrm{T}$. Changes in membrane properties of rat blood cells induced by cadmium accumulating in the membrane fraction. $J$ Biochem 1986;99:397-406.

31 Scott IG, Wolff HJ, Äkerman KEO, Andersson LC. Effects of $\mathrm{Cd}^{2+}$ upon $\mathrm{Ca}^{2+}$ fluxes and proliferation in concanavalin Astimulated lymphocytes. Exp Cell Res 1985;156:191-7.

Accepted 19 November 1990
"What!"

And then he explained that the wood they were using had come from France, from areas where there had been heavy fighting during the first world war and the trunks had bullets in them which had later disappeared into the depth of the tree as it grew. Then, when they came to cut the trees into planks, the saw would break if it came across a bullet, sending a piece of metal at colossal speed across the shop.

This seemed to be such an apocryphal story that I kept quiet about it for several years. Talking to a builder who was doing some work on my house, however, the conversation came round to occupational hazards, as it does, and he-without any prompting - told me the same story. He too had worked as a young man in a woodyard in which there had been bullets in the trees. This confirmed what I had heard before and I was now prepared to believe it. "And there was the musket," he went on. "What?" And he told me that one tree had been opened up and there in the middle, was a musket from the Napoleonic wars. At this point his credibility vanished; what next, a skeleton?

Can anyone verify this? Are there any other stories doing the rounds? Please let me know. 